\title{
Impact of Small and Medium Scale Enterprises on Employment Generation in Plateau State, Nigeria
}

\author{
Barnabas Gbam, $\mathrm{PhD}$ \\ NTA Television College, Jos Nigeria
}

\begin{abstract}
One of the major problems facing Nigeria today is unemployment. Establishment of Small and Medium Scale Enterprises (SMEs) is largely seen as a possible panacea to ameliorating the impact of unemployment in the society. This study examined the impact of SMEs on employment generation in Plateau State, Nigeria. Survey research method was adopted. A sample of one hundred and thirty three (133) small business owners was drawn from the population. The chi-square technique was employed for the analysis of the data collected. The findings show that SMEs have significant impact on employment generation in Plateau State through increased expansion of markets for local goods and services, improved economic growth and development, and a reduction in the unemployment problems of the state. It concludes that SMEs remains one of the most viable tools for job creation in Plateau State. In view of this, the study made some useful and practical recommendations to be adopted in order to encourage SMEs for greater employment generation. Among these are implementation of power sector reforms and stabilization of the power sector; control of religious, ethnic and political crisis; development of infrastructure such as roads, schools and vocational training centres.
\end{abstract}

\section{Introduction}

Small and Medium Enterprises (SMEs) development has continued to be a popular phrase in the Business world. This is because the sector serves as a catalyst for employment generation, national growth, poverty reduction and economic development. SMEs world over can boast of being the major employers of labour if compared to the major industries including the multinationals. According to Peterise (2003), SMEs both in the formal and informal sectors employ over $60 \%$ of the labour force in Nigeria. More so, $70 \%$ to $80 \%$ of daily necessities in the country are not high-tech products, but basic materials produced with little or no automation. Most of these products come from the Small and Medium Enterprises.

Right from independence in 1960, unemployment has been a rising phenomenon as many Nigerians are jobless to the extent that government itself may not actually know the rate of unemployment today. Many of the jobless persons have taken to crimes like armed robbery, drug trafficking and prostitution among others. This unemployment situation has been worsened by various factors peculiar to the Nigerian situation. These include poor planning or no planning at all, mono-economy, that is, total dependence on oil with its attendant price fluctuations in the world market, political and civil instability among others (Olagunju, 2008).

It is in realisation of the dangers of unemployment that the federal government has put in place policies and programmes such as the establishment of the National Directorate of Employment (NDE) in 1986 to work out strategies for dealing with the mass unemployment in the country especially among school leavers and university graduates. The essence of these efforts is to equip unemployed persons to be self reliant and self employed through acquisition of relevant skills in any trade of their choice as a means of earning a living. A person who has acquired a skill becomes an employer of labour instead of searching for a white collar job that is hardly available.

Consequently, many unemployed persons have taken the initiative to be self reliant rather than looking up to the government for employment. Today there are university or college graduates who have established businesses of their own and are carrying on well. Businesses ventured into include: Poultry farming, animal rearing, hairdressing, barbering, soap making, shoe production, baking, commercial transportation, distributive trade, estate agency, tailoring, laundry and dry cleaning, office and industrial cleaning, etc. All these enterprises are established and managed by individuals who desire to be economically independent and also want to contribute their quota to the development of the economy of the state and the nation at large. Today, such enterprises are spread all over the places, in the cities, towns and villages across the country (Nwoye, 1994).

What is interesting is that government (at various levels) is gradually beginning to realize that these enterprises could be the corner stone of the greatness of the Nigerian economy. Perhaps this is why various governments are doing one thing or the other to promote and encourage the development of SMEs as a panacea to youth unemployment.

Plateau State, being one of the thirty-six states that make up the Federal Republic of Nigeria, has put in place some measures to promote and encourage the development of SMEs. These include financing, provision 
of infrastructural facilities, policies and moral encouragement among others. It is against the above background that this study seeks to ascertain the exact impact of these efforts on employment generation in Plateau State.

Plateau State over the years has been known as a civil service state by its inhabitants. The reason for this name being that the aspiration or dream of the average Plateau school leaver or graduate is to secure a job with the state government, and not with the private sector, let alone to be self employed. Little wonder, most of the business ventures that are fast growing on the plateau are owned by settlers and not by plateau natives. Unfortunately, the existing vacancies in the state civil service cannot absorb all job seekers in the state. To worsen the situation, there has not been an official recruitment into the state ministries for the last eight (8) years. This scenario has undoubtedly raised the unemployment profile or index of the state.

In Nigeria as a whole, unemployment rate has been on the increase in spite of the fact that government has made frantic efforts in creating employment opportunities since the transition to civil rule in 1999. The growing number of graduates and school leavers churned out annually from various institutions of learning in the country makes government efforts to have little or no impact as far as the issue of unemployment is concerned. Statistics shows that unemployment rate stands at an average of about 23.9\% (NBS, 2011). Furthermore, the ILO (2007) noted that the increase in the number of youths in secondary and tertiary education is another development. However, the labour market in Nigeria is presently unable to accommodate the expanding pool of young graduates. Apparently, the various tiers and arms of government in Plateau State cannot meaningfully engage the teaming school leavers that are churned out annually from the various schools and tertiary institutions.

In the above situation, small and medium scale enterprises are expected to come to the rescue of both the graduates and the state government by providing the much needed jobs. This study thus examines the extent to which small scale enterprises have impacted on the generation of employment for youths in Plateau State, Nigeria.

\section{Objectives Of The Study}

The primary aim of this study is to ascertain the impact of SMEs on employment generation in Plateau State. The specific objectives include:

i. To determine the extent to which SMEs have impacted on employment generation in Plateau State, Nigeria.

ii. To identify specific ways SMEs can create employment opportunities in Plateau State.

iii. To highlight some specific small scale enterprises opportunities available for Plateau State residents.

iv. To identify the problems of small scale enterprises in Plateau State.

\section{Research Questions}

In order to achieve the objectives of the research work, the researcher attempts to address the following research questions:

i. To what extent have SMEs impacted on employment generation in Plateau State, Nigeria?

ii. In what specific ways do SMEs create employment opportunities in Plateau State?

iii. What are the specific small scale enterprises opportunities available for Plateau State residents?

iv. What are the problems of small scale enterprises in Plateau State?

\section{Research Hypotheses}

The main purpose of this research is to determine the impact of SMEs on employment generation in Plateau State. Therefore the following hypotheses are tested in this study using 5\% level of significance:

Ho: Small Scale Enterprises have no significant impact on employment generation in Plateau State.

Hi: Small Scale Enterprises have significant impact on employment generation in Plateau State.

Ho: Employment generation has no significant effect on the economic development of Plateau State.

Hi: Employment generation has significant effect on the economic development of Plateau State

\section{Literature Review}

Lawal, (2002) opines in Safiryu and Njogo (2012) that there is no universal definition of small scale industry. Definition also changes overtime, owing to changes in price level, advances in technology and other considerations. The criteria that may be used in defining small and medium scale enterprises (SMEs) often include turnover, gross output and employment. Bolton Report (1971) also added the characteristics basis as one of the recommended alternatives in giving SMEs adequate and appropriate definition. These characteristics include small market share, operated independently and managed by its owners or part-owners in a personalized way. These factors are usually used because they are functional and easy to measure.

According Onmonya (2011), the European Union (EU) in 1996, gave the definition of Micro Small and Medium Enterprises (MSMEs) as an enterprise employing less than 250 employees. These were further 
categorized into Micro, not more than 10 employees; Small scale, more than 10 but less than 50 employees; and Medium scale, more than 50 but not exceeding 250 employees.

A working definition by International Labour Organization (ILO) and United Nations Development Programme (UNDP) for SMEs and large enterprises indicates that: employing less than 5 employees including the owner is a micro enterprise; employing 5 to 20 employees is a small enterprise; employing 21 to 99 employees is a medium enterprise; and employing above 99 employees is a large enterprise (UNDP, 2001).

The Central Bank of Nigeria (CBN) redefined small enterprises (excluding) commerce) as enterprises in which total investment (including land and capital) does not exceed N500,000 and/or annual turnover does not exceed N5million. Following the persistent depreciation of the naira, capital investment was raised to N5million and turnover to N25million (Gadi, 2013).

In 1992, the National Council of Industry (NCI) streamed the definition of industrial enterprises for recurrent review every four years. There was a revised edition in 1996. In July 2001, the National Council of Industry at its $13^{\text {th }}$ meeting in Markurdi, Benue State (NCI-13) made the following revisions:

\section{Micro/Cottage Industry}

That is an industry with total capital employed of not more than N1.5 million including working capital but excluding cost of land and or a labour size of not more than 10 workers.

\section{Small-Scale Industry}

An industry with total Capital employed of over N15 million but not more than N50 million, including working capital but excluding cost of land, and or labour size of 11-100 workers.

\section{Medium-Scale Industry}

An industry with a total capital employed of over N50 million but not more than N200 million, including working capital but excluding cost of land, and or a labour size of 101-300 workers.

\section{Large-Scale Industry}

An industry with a total capital employed of over N200 million, including working capital but excluding cost of land or a labour size of over 300 workers. Comparatively, most advanced countries seemed to have agreed on a maximum limit of 500 employees as a small Firm.

Unemployment is generally regarded as a symptom of basic microeconomic disequilibrium. What is, however, controversial is the appropriate conceptualization of the subject matter. Much controversy over the definition of unemployment revolved around the distinction between "voluntary" unemployment. Voluntary unemployment is said to exist when persons choose not to work or accept job for which they are qualified at the going wage rate and conditions probably because they have means of support other than employment. On the other hand, involuntary unemployment exists when persons cannot obtain work/job for which they are qualified even if they are willing to accept lower real wages or poor conditions than similar qualified workers who are currently in employment (Anyanwu \& Oaikhena, 1995).

The International Labour Organisation (ILO) defines the unemployed as members of the economically active population, who are without work but available for and seeking for work, including people who have lost their jobs and those who have voluntarily left work (World Bank, 1998). According to Casson (1979), an unemployed person is someone who is actively seeking a job of certain specification and would be willing to accept such a job if it were offered at the prevailing market wage.

Jhingan (2010) defines unemployment as "involuntary idleness of a person willing to find work". This implies that voluntarily unemployed persons who do not want to work are not considered unemployed. In the view of Douglason and Gbosi (2006), unemployment is the difference between the amount of labour employed at current wage levels and working conditions and the amount of labour not hired at these levels.

Employment is no just a simple term denoting the mere holding of a job, in which a wage is paid or the operating of one's business venture. Rather, it entails the state of someone who is working under the circumstances he most wants. Such a person is said to be gainfully employed.Douglason and Gbosi (2006) defines employment as a situation in which people who are willing to work at the prevailing wage rate are able to find jobs. In his view, Mouly (1972), perceived employment as a situation in which remuneration in cash or in kind is received in exchange for active, direct participation in the production process. Wikipedia, the free encyclopedia defines employment as a relationship between two parties, usually based on a contract where work is paid for, where one is the employer and the other is the employee. 


\section{Research Design}

The study adopted survey research design. Copies of questionnaire served as instrument for data collection, and the generated data were analysed using Chi-Square. The total population of Plateau state according to the 2006 National Population Commission census figures was three million, one hundred and seventy eight thousand, seven hundred and twelve $(3,178,712)$. A total of 200 respondents were purposefully selected as the sample size. The simple random sampling technique was further adopted to give equal opportunity of selection to every element of the population.

Chi-Square was used to test the hypotheses. Data were presented and analyzed using simple statistical tables and percentages. The value of the Chi-Square was calculated using the formula;

$$
\Sigma \times 2=\frac{\mathrm{Fo}-\mathrm{Fe}}{\mathrm{Fe}}
$$

Where; $\mathrm{X}^{2}=$ Chi Square

$\mathrm{Fo}=$ observed frequency

$\mathrm{Fe}=$ expected frequency of data collected

$\Sigma=$ summation sign

The expected frequency is derived by the formula below:

$\mathrm{Fe}=$

$\frac{\text { RT X CT }}{\text { GT }}$

Where RT $=$ Row Total

$\mathrm{CT}=$ Column Total

$\mathrm{GT}=$ Grand Total

Level of significance $=0.05$

Degree of freedom is calculated using the formula;

$\mathrm{df}=(\mathrm{R}-1)(\mathrm{C}-1)$

Where $\mathrm{df}=$ degree of freedom

$\mathrm{C}=$ number of columns

$1=$ consistent

$\mathrm{R}=$ number of rows

\section{Decision Criteria:}

The researcher shall determine whether to accept to or reject the null or alternative hypothesis. The decision rule is that;

1. If the calculated $\mathrm{X}^{2}$ is more than the tabulated value of $\mathrm{X}^{2}$, the null hypothesis (Ho) is not to be accepted and the alternative hypothesis $(\mathrm{Hi})$ is to be accepted.

2. If the calculated $\mathrm{X}^{2}$ is less than the table value of $\mathrm{X}^{2}$, the null hypothesis (Ho) is accepted.

\section{Data Presentation}

Out of the 200 copies of the questionnaire distributed, 120 were correctly filled and returned. The data are presented below:

\section{Data Presentation}

Table 1: Does Small and Medium scale Enterprise have significant impact on employment generation in Plateau State?

\begin{tabular}{|l|l|l|l|l|l|l|l|}
\hline \multicolumn{3}{|c|}{ FREQUENCY } & \multicolumn{5}{c|}{ PERCENTAGE (\%) } \\
\hline Yes & No & Unsure & Total & Yes & No & Unsure & total \\
\hline 113 & 2 & 5 & 120 & 94.2 & 1.7 & 4.1 & 100 \\
\hline
\end{tabular}

Source: Field 2016

From table 1 above, it can be seen that one hundred and thirteen (113) respondents agreed that Small and Medium Scale Enterprises have significant impact on employment generation in Plateau State, whereas two (2) respondents disagreed and five (5) of the respondents were unsure.

Table 2: Have SMEs been able to reduce the unemployment problem in Plateau State?

\begin{tabular}{|l|l|l|l|l|l|l|l|}
\hline \multicolumn{3}{|c|}{ FREQUENCY } & \multicolumn{5}{c|}{ PERCENTAGE (\%) } \\
\hline Yes & No & Unsure & Total & Yes & No & Unsure & total \\
\hline 15 & 2 & 3 & 120 & 95.8 & 1.7 & 2.5 & 100 \\
\hline
\end{tabular}

Source: Field 2016 
One hundred and fifteen (115) respondents were of the opinion that SMEs have been able to reduce the unemployment problem in Plateau State, while two (2) respondents disagreed and three (3) of the respondents were not sure as shown in table 2 above.

Table 3: Have SMEs been able to increase the economic growth and development in Plateau State?

\begin{tabular}{|l|l|l|l|l|l|l|l|}
\hline \multicolumn{4}{|c|}{ FREQUENCY } & \multicolumn{5}{c|}{ PERCENTAGE (\%) } \\
\hline Yes & No & Unsure & Total & Yes & No & Unsure & total \\
\hline 111 & 4 & 5 & 120 & 95.5 & 3.3 & 4.2 & 100 \\
\hline
\end{tabular}

Source: Field 2016

Table 3 reveals that one hundred and eleven (111) respondents had the view that SMEs have been able to increase the economic growth and development in Plateau State, whereas four (4) respondents had a contrary view and five (5) of these respondents were unsure.

Table 4: Has the expansion of markets for local goods and services in Plateau State been impacted by SMEs?

\begin{tabular}{|l|l|l|l|l|l|l|l|}
\hline \multicolumn{4}{|c|}{ FREQUENCY } & \multicolumn{5}{c|}{ PERCENTAGE (\%) } \\
\hline Yes & No & Unsure & Total & Yes & No & Unsure & total \\
\hline 97 & 15 & 8 & 120 & 80.8 & 12.5 & 6.7 & 100 \\
\hline
\end{tabular}

Source: Field 2016

It is shown in table 4 that ninety-seven (97) respondents were of the opinion that the expansion of markets for local goods and services in Plateau State has been impacted by SMEs, while fifteen (15) respondents thought otherwise and eight (8) of the respondents were not sure.

Table 5: Can government participation in SMEs improve its performances for employment generation in

\begin{tabular}{|l|l|l|l|l|l|l|l|}
\hline \multicolumn{4}{|c|}{ FREQUENCY } & \multicolumn{5}{c|}{ PERCENTAGE (\%) } \\
\hline Yes & No & Unsure & Total & Yes & No & Unsure & total \\
\hline 111 & 3 & 6 & 120 & 92.5 & 2.5 & 5.0 & 100 \\
\hline
\end{tabular}

Source: Field 2016

From table 5 above, it can be seen that one hundred and eleven (111) respondents are of the opinion that government participation in SMEs can improve its performances for employment generation in Plateau State, whereas three (3) respondents had a contrary opinion and six (6) of the respondents were unsure.

Table 6: Is the SME sub sector confronted with any form of challenges in employment generation in Plateau

\begin{tabular}{|c|c|c|c|c|c|c|c|}
\hline \multicolumn{8}{|c|}{ State? } \\
\hline \multicolumn{4}{|c|}{ FREQUENCY } & \multicolumn{4}{|c|}{ PERCENTAGE (\%) } \\
\hline Yes & $\mathrm{No}$ & Unsure & Total & Yes & No & Unsure & total \\
\hline 115 & 0 & 5 & 120 & 95.8 & 0 & 4.2 & 100 \\
\hline
\end{tabular}

Source: Field 2016

As revealed in table 6 above, one hundred and fifteen (115) respondents agreed that the SME sub sector is confronted with some form of challenges in generating employment in Plateau State, whereas five (5) of the respondents were unsure and none of the respondents disagreed to that.

Table 7: Has there been any effort from both the public and the private sector to reduce the challenges faced by the SME sub sector in Plateau State?

\begin{tabular}{|l|l|l|l|l|l|l|l|}
\hline \multicolumn{3}{|c|}{ FREQUENCY } & \multicolumn{5}{c|}{ PERCENTAGE (\%) } \\
\hline Yes & No & Unsure & Total & Yes & No & Unsure & total \\
\hline 91 & 20 & 9 & 120 & 75.8 & 61.7 & 7.5 & 100 \\
\hline
\end{tabular}

Source: Field 2016

It is shown in table 7 that ninety-one (91) respondents were of the view that there have been some efforts from both the public and the private sectors to reduce the challenges faced by the SME sub sector in Plateau State, whereas twenty (20) respondents had a contrary view and nine (9) of the respondents were not sure. 
Table 8: Have these support agencies or programmes been effective in encouraging SMEs in Plateau State?

\begin{tabular}{|l|l|l|l|l|l|l|l|}
\hline \multicolumn{3}{|c|}{ FREQUENCY } & \multicolumn{5}{c|}{ PERCENTAGE (\%) } \\
\hline Yes & No & Unsure & Total & Yes & No & Unsure & total \\
\hline 86 & 22 & 12 & 120 & 71.6 & 18.4 & 10 & 100 \\
\hline
\end{tabular}

Source: Field 2016

As shown in table 8, eight six (86) respondents were of the opinion that these support agencies or programmes have been effective in encouraging SMEs in Plateau State, while twenty two (22) respondents thought otherwise and twelve (12) of the respondents were not sure.

\section{Data Analysis And Interpretation}

Data were analyzed by the use of the chi-square technique to test the hypotheses. The level of significance adopted for the test of hypothesis is $5 \%$.

\section{Test Of Hypothesis}

Table 9: Contingency Table Of Observed (Fo) And Expected (Fe) Frequency

\begin{tabular}{|l|l|l|l|l|}
\hline & & & & \\
\hline QUESTION & YES & NO & UNSURE & TOTAL \\
\hline 1 & $133(107.4)$ & $2(8.3)$ & $5(6.4)$ & 120 \\
\hline 2 & $115(107.4)$ & $2(8.3)$ & $3(6.4)$ & 120 \\
\hline 3 & $111(107.4)$ & $4(8.3)$ & $5(6.4)$ & 120 \\
\hline 4 & $97(107.4)$ & $15(8.3)$ & $8(6.4)$ & 120 \\
\hline 5 & $108(107.4)$ & $7(8.3)$ & $5(6.4)$ & 120 \\
\hline 6 & $111(107.4)$ & $3(8.3)$ & $6(6.4)$ & 120 \\
\hline 7 & $115(107.4)$ & $0(8.3)$ & $5(6.4)$ & 120 \\
\hline 8 & $91(107.4)$ & $20(8.3)$ & $9(6.4)$ & 120 \\
\hline 9 & $86(107.4)$ & $22(8.3)$ & $12(6.4)$ & 120 \\
\hline Total & 967 & 75 & 58 & 1080 \\
\hline
\end{tabular}

Source: Responses of Questionnaire

From the above table, the figures in the bracket represent the expected frequency $(\mathrm{Fe})$ while those figures outside the bracket represent the observed frequency (Fo).

The expected frequency was computed using the formula: $\mathrm{Fe}=$

$\underline{\text { RT-CT }}$

Where:

$\mathrm{GT}$

$\mathrm{Fe}=$ Expected Frequencies

RT $=$ Row Total

GT $=$ Grand Total

$\mathrm{CT}=$ Column Total

As it is shown in table 4.3a above, see appendix II for details on the computation.

Table 10: Contingency Table Of Calculated CHI-Square

\begin{tabular}{|l|l|l|l|l|l|}
\hline Row and column & Fo & Fe & Fo-Fe & $(\mathrm{Fo}-\mathrm{Fe}) 2$ & $\frac{(\mathrm{Fo}-\mathrm{Fe})^{2}}{\mathrm{Fe}^{2}}$ \\
\hline RICI & 133 & 107.4 & 25.6 & 655.36 & 6.10 \\
\hline R1C2 & 2 & 8.3 & -6.2 & 38.44 & 4.63 \\
\hline R1C3 & 5 & 6.4 & 6.4 & 1.96 & 0.31 \\
\hline R2C1 & 115 & 107.4 & 7.6 & 57.76 & 0.54 \\
\hline R2C2 & 2 & 8.3 & -6.3 & 39.69 & 4.78 \\
\hline R2C3 & 3 & 6.4 & -3.4 & 11.56 & 1.81 \\
\hline R3C1 & 111 & 107.4 & 3.6 & 12.96 & 0.12 \\
\hline R3C2 & 4 & 8.3 & -4.3 & 18.49 & 2.23 \\
\hline R3C3 & 5 & 6.4 & -1.4 & 1.96 & 0.31 \\
\hline R4C1 & 97 & 107.4 & -10.4 & 108.16 & 1.01 \\
\hline R4C2 & 15 & 8.3 & 6.7 & 44.89 & 5.41 \\
\hline R4C3 & 8 & 6.4 & 1.6 & 2.56 & 0.40 \\
\hline R5C1 & 108 & 107.4 & 0.6 & 0.36 & 0.03 \\
\hline R5C2 & 7 & 8.3 & -1.3 & 1.69 & 0.21 \\
\hline R5C3 & 5 & 6.4 & -1.4 & 1.96 & 0.31 \\
\hline R6C1 & 111 & 107.4 & 3.6 & 12.96 & 0.12 \\
\hline R6C2 & 3 & 8.3 & -5.3 & 28.09 & 3.38 \\
\hline R6C3 & 6 & 6.4 & -0.4 & 0.16 & 0.03 \\
\hline
\end{tabular}




\begin{tabular}{|l|l|l|l|l|l|}
\hline R7C1 & 115 & 107.4 & 7.6 & 57.76 & 0.54 \\
\hline R7C2 & 0 & 8.3 & -8.3 & 68.89 & 8.3 \\
\hline R7C3 & 5 & 6.4 & -1.4 & 1.96 & 0.31 \\
\hline R8C1 & 91 & 107.4 & -16.4 & 268.96 & 2.51 \\
\hline R8C2 & 20 & 8.3 & 11.7 & 136.89 & 16.5 \\
\hline R8C3 & 9 & 6.4 & 2.6 & 6.76 & 1.05 \\
\hline R9C1 & 86 & 107.4 & -21.4 & 457.96 & 4.26 \\
\hline R9C2 & 22 & 8.3 & 13.7 & 187.69 & 22.6 \\
\hline R9C3 & 12 & 6.4 & 5.6 & 31.36 & 4.9 \\
\hline SUM & & & & & 92.673 \\
\hline
\end{tabular}

From the table $\mathrm{X}^{2}=92.673$

\section{Test of Significance}

The above statistical computation is tested at $0.05(5 \%)$ level of significance and 16 degree of freedom (df) is used. The degree of freedom is obtained by:

Df $=($ Row-1) $($ column -1$)$

$\mathrm{Df}=(9-1)(3-1)$

$\mathrm{Df}=(8)(2)$

$\mathrm{Df}=16$

The critical (tabulated) value of $X^{2}=26.296$, while the calculated value of $X^{2}=92.673$

\section{Decision Rule:}

From the above statistical test, since the calculated value of $X^{2}$ (92.673) is greater than the critical (tabulated) value of $\mathrm{X}^{2}$ (26.296), we therefore reject the null hypothesis $\left(\mathrm{H}_{0}\right)$ in favor of the alternative hypotheses $\left(\mathrm{H}_{1}\right)$ and then conclude that SMEs have significant impact on employment generation in Plateau State.

Furthermore, the result obtained and the decision taken from our tested hypothesis implies that SMEs have significant impact on job creation and by extension economic development of Plateau State as the difference between the calculated chi-square of $X^{2}=92.673$ and the critical value of $X^{2}=26.296$ greatly reveals and confirms our prior expectation.

\section{Conclusion}

SMEs development has been seen as a means of generating greater employment opportunities, conserving foreign exchange earnings and stimulating economic growth and development of any country. The unacceptable rate of youth unemployment in Plateau State is the main motivator of this study. After successfully carrying out the research, the findings reveal that SMEs have significant impact on employment generation in Plateau State through increased expansion of markets for local goods and services, improved economic growth and development, and a reduction in the unemployment problems of the state.

The contributions of these SMEs have been quiet strengthened by both private and government participation through various support agencies and programmes. These SMEs, however, encounter several challenges as they strive towards creating the much needed jobs. But notwithstanding, there are good prospects for their growth and development as great opportunities abound in the state.

Based on the findings from this work, it can be confidently concluded that Small and Medium Scale Enterprises have significant impact on employment generation and remains one of the most viable tools for job creation in Plateau State. This is evident in the fact that SME is one of the biggest employers of labour, generating employment for millions of people in various economic activities such as: weaving, hairdressing, handset repairs, poultry farming, beads making, carpentry, sewing, bakery and manufacturing of other industrial products. If proper attention is given to the sector, it is capable of reducing unemployment to the barest minimum and generating the highest earnings for the state and country at large. Therefore, to achieve full employment and to be among the topmost 20 developed countries of the world by the year 2020, the SME sub sector must be given all the desired attention and support from the national, state and local governments as well as Non Governmental Organizations (NGO's) as this will provide an avenue for sustainable employment generation and economic development as a whole.

\section{Recommendations}

The following are the recommendations that will promote efforts to generate more employment opportunities through SMEs:

i. Government should intensify its efforts in reforming and stabilizing the power sector so as to put an end to the energy crisis and epileptic power supply in the state and country at large. 
ii. Business activities can only thrive in an atmosphere of peace; hence, religious, ethnic and political violence should be controlled by all means necessary.

iii. Support and sponsorship for SMEs should be devoid of politics and favoritism in terms of finance as it is one of the major problems of SMEs development in the state.

iv. Governments should develop the local technological base of the country as most SMEs use obsolete and outdated technology which makes their production difficult. This can be done by transfer of technology.

v. Infrastructural facilities such as roads, water, communication, hospitals and vocational training centres should be well developed as it will help in reducing the cost of doing business for these SMEs.

vi. Government policies and programmes geared towards training youths in various skills and businesses should be proactive and pragmatic in meeting the dynamic and constant changing business environment given the current state of the economy.

\section{References}

[1]. Peterson, M.A. \& Rajan, R.G. (1994). The Benefit of Firm Creditors Relationship: Evidence From Small Business Data. Journal of Finance Vol. 49, pp 337.

[2]. Olagunju, Y. A. (2008). Entrepreneurship and Small Scale Business Enterprises Development in Nigeria. Ibadan: University Press Plc.

[3]. Nwoye, M. (1994). Small Business Enterprises. Benin: Social Science Series for African University of Benin.

[4]. ILO (2011). Global Employment Trends 2011. Retrieved October 20, 2011 from www. ILO.org/wcmsp5/groups/public/.../@public/.../wcm515044.pdf.

[5]. Safiriyu, A. M. \& Njogo, B. O. (2012). Impact of Small and Medium Scale Enterprises in the Generation of Employment in Lagos State.I Kuwait Chapter of Arabian Journal of Business and Management Review. Vol.1, No 11; July 2012.

[6]. Onmonya, L. O. (2011). Intrepreneurship and New Venture Management. Abuja: Issues and Company Ltd.

[7]. UNDP (1999). Entrepreneurship Development. Essentials, 2, December.

[8]. Jhingan, M. L. (2010). Macroeconomics Theory, $12^{\text {th }}$ edition. Delhi: Vrinda Public.

[9]. Douglason, G. U. \& Gbosi, A. (2006). The Dynamics of Productivity and Unemployment Nexus: Implication for Employment Generation in Nigeria NES 2006. Annual Conference, Ibadan.

[10]. Anyanwu, J. C. \& Oaikhenan, H. E. (1995). Modern Macroeconomics: Theories and Application in Nigeria. Onitsha: Joanee Educational Publishers Ltd.

[11]. Gadi, P.D. (2013). Entrepreneurship and Small Business Management (Tools for Success). Jos: PG Publishers.

[12]. Awogbenle, A. C. \& Iwuamadi, K. O. (2010). Youth Unemployment Entrepreneurship Development Programme as an Intervention Mechanism. African Journal Business. Management, 4 (6): pp. 831-835.

[13]. Nigeria Bureau of Statistic (2011). 2011 Annual Performance Report of the Nigeria Economy, the Presidency, National Planning Commission. Abuja, Nigeria.

[14]. Mayat, A. A. \& Ruth, P. G. (2010). Manual for Entrepreneurship and Small Business. Jos: G-taf Press.

[15]. Assundani, R. H. (2009). Ethnic Entrepreneurship:The Distinct Role in Ties. Journal of Business Entrepreneurship. $22(2)$.

[16]. Ariyo, D. (2008). Small Firms are the Backbnone of the Nigeria Economy. April 11 ${ }^{\text {th }}$, 2008. Retrieved from http://www.africaeconomicanalysis.org.

[17]. Barret, G. C. (1999). Overcoming Obstacles: Access to Bank Finance for Africa Caribbean Enterprise. Journal of Ethnic and Migration Studies. 25(2) pp 30.

[18]. Carree, M. A. \& Thurik, A. R. (2002). International Handbook of Entrepreneurship Research. Zottan Acs and David Audretsch (eds).

[19]. Casson, M. (1999). Youth Employment: Guilford, London: Billing and Sons Ltd. Definition of Employment. Retrieved from https://en.m.wikipedia.org/wiki/Employment. Accessed January 30th, 2015.

[20]. Dollinger, M. J. (2003) Entrepreneurship: Strategies and Resources, ( $3^{\text {rd }}$ edition). Singapore: Pearson Education Ltd.

[21]. Druck, P.F. (1985). Innovation and Entrepreneurship: Practice and Principles. London: Williams Heinemana Ltd.

[22]. John, O.U. (1999). Entrepreneurship in the $21^{\text {st }}$ Century, ( $1^{\text {st }}$ edition). CID SAP Publication.

[23]. Kirzner, I. M. (1973). Competition and Entrepreneurship. Chicago: University of Chicago Press. 